\title{
Study of knowledge, attitude, and practice regarding birth spacing and methods available for spacing in rural Haryana, India
}

\author{
Bindoo Yadav, Santvana Pandey*
}

Department of Obstetrics and Gynecology, SGT Medical College Hospital and Research Institute, Budhera, Gurgaon, Haryana, India

Received: 06 March 2018

Accepted: 13 March 2018

*Correspondence:

Dr. Santvana Pandey,

E-mail: dr.pandey@gmail.com

Copyright: () the author(s), publisher and licensee Medip Academy. This is an open-access article distributed under the terms of the Creative Commons Attribution Non-Commercial License, which permits unrestricted non-commercial use, distribution, and reproduction in any medium, provided the original work is properly cited.

\section{ABSTRACT}

Background: Birth spacing is defined as the time interval between two births. India has average birth spacing of 22 months, i.e. little less than two years, despite wide knowledge of contraception. Objective of present study was to investigate the knowledge, attitude, and practice regarding birth spacing and methods available for spacing in rural Haryana amongst sexually active married females of reproductive age.

Methods: Cross sectional study of 500 sexually active, married females of reproductive age with at least one live issue and not meeting any exclusion criteria was carried at SGT medical college, Gurgaon during 3 months from August 2017.

Results: Awareness of need for birth spacing was very high (82.6\%) in females interviewed, with $70 \%$ of females being aware of birth spacing benefits as well as keen to opt for birth spacing but even higher count of females (92.6\%) reporting requiring husband's consent for birth spacing. Only $40 \%$ females were practising birth spacing with $14.6 \%$ of females reporting in-law's opposition as reason for not practising birth spacing.

Conclusions: Education is a major factor improving awareness of need as well as benefits of child spacing, with all college studied females being aware of both. Education also leads to improvement in keenness for practising child spacing as well as having lesser opposition to practise of child birthing. Females with only girl child/children were less keen to practise child spacing. Rural geographies still have health personnel as significant source imparting awareness of child spacing.

Keywords: Attitude, Birth spacing, Contraception, Family planning, Knowledge, Practice

\section{INTRODUCTION}

Birth spacing is defined as the time interval between two births. India has average birth spacing of 22 months, i.e. little less than two years, despite wide knowledge of contraception. $^{1,2}$ It is an important lever by which improved maternal-child health and further reduction in the indices such as Maternal Mortality Ratio (MMR, female deaths per 100,000 live births from any cause related to or aggravated by pregnancy or its management, excluding accidental or incidental causes) can be assured.
Short birth spacing or inter-pregnancy intervals (IPIs, time interval between a live birth and the beginning of the next pregnancy) are associated with negative maternal health outcomes as well as negative perinatal, neonatal, infant health outcomes. ${ }^{3}$ The concept of optimal birth spacing of 24 months is mentioned in a report published by WHO in 2005. Other studies focusing on related aspect, such as Conde-Agudelo et al, have also found shorter than 18 months of inter-pregnancy intervals linked with significant maternal-child health concerns. ${ }^{3,4}$ As per a study among post-partum patients, by Patel et al, 
level of awareness of contraception was $63.2 \%$, while it was $100 \%$ as per study by Nayak et al, but the acceptance of contraception still remain quite low in other studies (only $15 \%$ in above study by Patel et al). ${ }^{5-7}$ Thus, while knowledge of birth spacing has reached a substantial level, conversion of this knowledge into a change of attitude and thence to practice of birth spacing appears lagged. This lag would lead to slowing of improvement in maternal health indices.

Amongst Indian states, Haryana is one of the wealthiest with INR 1.3 lac per capita income in the year 201314. ${ }^{8,9}$ Despite this, Haryana has quite slightly lower than average birth spacing across India and a high MMR of 127 per 100,000 live births. ${ }^{1,8,9}$ Although MMR is substantially lower than national average, yet it is much higher than similarly well-off states with high development indices such as Maharashtra and Tamilnadu.

A study by Kanojia et al, in urban population of Mumbai, reported that Education was the main variable in the decisions regarding the family size, spacing interval, contraceptive awareness, its use immediately after marriage and during the postpartum period. Spacing methods were popular among the educated and terminal ones among the uneducated. ${ }^{7}$ Average birth spacing interval still remains quite low in India with a substantial number of births occur with lower than 24 month interpregnancy intervals, a study by Chandna et al, found. ${ }^{2}$

Our study focused on the women of rural Haryana to provide insights for health care setups in Haryana or similar low socio-economical geographies. This study strove to bridge the gap of not having birth descriptive spacing data for rural Haryana.

\section{METHODS}

The present study was a prospective cross sectional study. 500 Sexually active married women of reproductive age, and consenting to participate in study, were interviewed for this study. The study was conducted in the department of obstetrics and gynaecology, SGT medical college and hospital during 3 month period from August 2017 to October 2017. 500 women who fulfilled the inclusion criteria were interviewed for the study.

\section{Eligibility criteria were}

- Women of reproductive age group

- Women who have atleast one live issue.

\section{Exclusion criteria}

- Unmarried women

- Not sexually active

- Age $>45$ years

- PCOD

- Infertility

- DUB
Patients who fulfilled the inclusion criteria were explained about the procedure and written informed consent was taken.

Detailed information about recruited females was collected by standardised questionnaire, which included demographic details such as age, education, income. Following specific areas of knowledge, attitude and practice related to birth spacing and methods used for spacing was noted:

- Knowledge of need for birth spacing

- Knowledge of contraception as means of birth spacing

- Knowledge of benefits related to birth spacing

- Source of knowledge related to contraception, birth spacing

- Application of birth spacing for planning their family

- Reasons for not spacing

- Methods deployed for spacing.

\section{RESULTS}

A total number of 500 females participated in the study. Interviewed female's characteristics in terms of age, gravida, spousal age, income, education and child's sex were recorded.

Table 1: Study group characteristics.

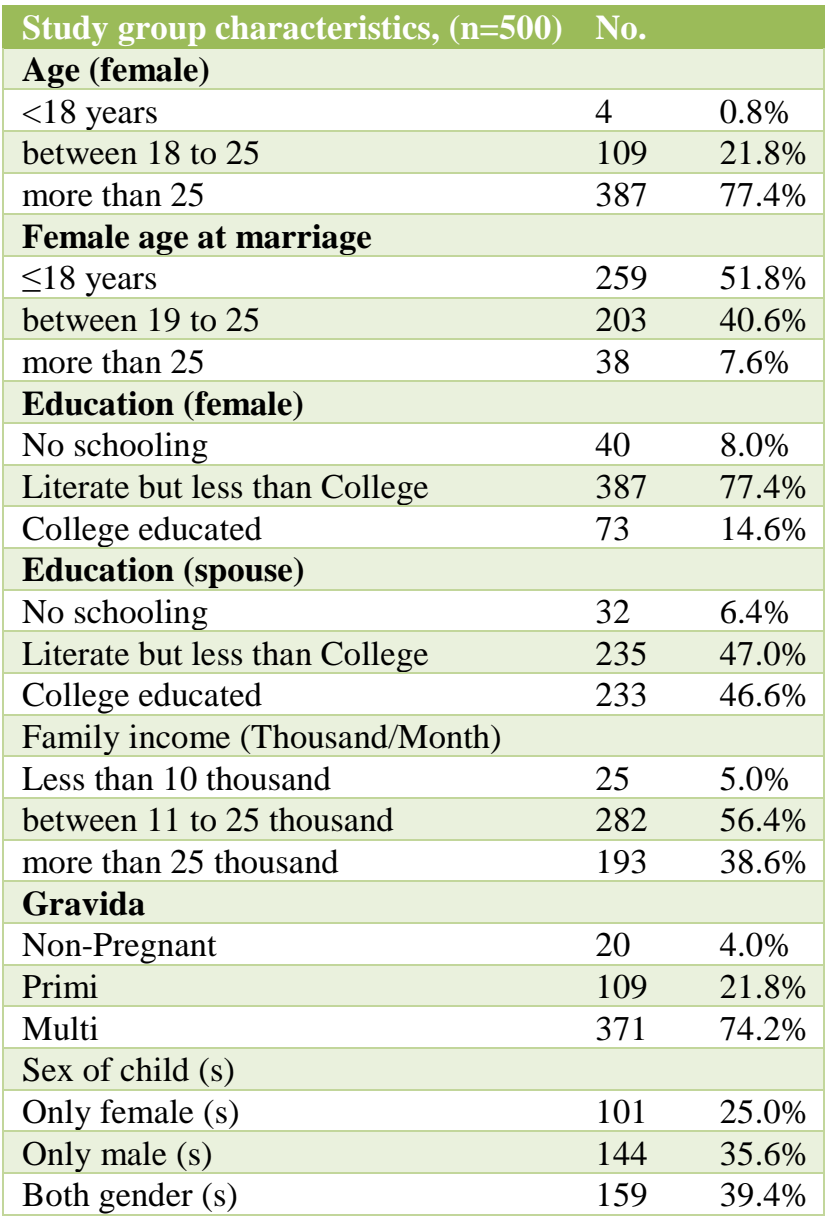


Majority of females had been literate $(92 \%)$ as well as married to literate person $(93.4 \%)$, as well as being in age group of $\geq 20$ years $(97 \%)$. Majority of the interviewed females had been married at $\leq 18$ years $(51.8 \%)$, with substantially less number $(32 \%)$ literate females marrying at age of $\leq 18$ years.

\section{Knowledge}

Most of the 500 females who participated in the study knew of means of birth spacing $(86.4 \%)$ although lesser number actually knew of need for birth spacing (82.6\%). The knowledge of means of birth spacing came from health personnel (from primary health clinics/Asha workers/hospitals etc.) which contributed to $21.5 \%$ (of aware females) highlighting the continued importance and impact of community health initiatives in rural settings.

Table 2: Knowledge about birth spacing.

\begin{tabular}{|lll|}
\hline Knowledge of need for birth & No. & $\%$ \\
\hline spacing, (n=500) & 413 & $82.6 \%$ \\
\hline Yes & 87 & $17.4 \%$ \\
\hline No & \multicolumn{2}{l|}{} \\
\hline Benefits of child spacing & 131 & $26.2 \%$ \\
\hline No Idea & 154 & $30.8 \%$ \\
\hline New born's rearing & 68 & $13.6 \%$ \\
\hline Mother's health & 92 & $18.4 \%$ \\
\hline Mother's and child's health & 19 & $3.8 \%$ \\
\hline Mother's work responsibilities & 36 & $7.2 \%$ \\
\hline Next child's health & 93 & $18.6 \%$ \\
\hline Where did you first learn about birth spacing \\
\hline Health workers & 183 & $32.6 \%$ \\
\hline Family/friends & 59 & $11.8 \%$ \\
\hline Magazine & 117 & $23.4 \%$ \\
\hline TV/radio & 68 & $13.6 \%$ \\
\hline No Idea of birth spacing & 276 & $55.2 \%$ \\
\hline Means of birth spacing (many knew multiple & means) \\
\hline Copper T & 247 & $49.4 \%$ \\
\hline Pills & 107 & $21.4 \%$ \\
\hline Condoms & 15 & $3.0 \%$ \\
\hline Tubectomy & 147 & $29.4 \%$ \\
\hline Withdrawal & 68 & $13.6 \%$ \\
\hline No Idea & \multicolumn{2}{|c|}{} \\
\hline
\end{tabular}

A significant percentage of interviewed females did not know specific benefits of birth spacing (26.2\%) while a small percentage linked it to taking care of domestic/work responsibilities post child birth (3.8\%). Remainder of interviewed females were able to link child spacing to health reasons, including newborn's rearing and mother's health.

Literate females were mostly aware of benefits of child spacing $(86 \%)$, with all college educated females being aware as well as able to link benefits of child spacing to mother and child's health (100\%). Female education thus is most significant factor for improvement of child spacing awareness.

Most of females who knew need of child spacing also knew of means of child spacing (97\%) with majority of aware females knowing multiple means of child spacing (90\%). Copper T and OCP were most commonly known means of child spacing, while withdrawal was also known as means of child spacing (29.4\%). Some less educated females (schooling less than $5^{\text {th }}$ standard) mentioned tubectomy as means of child spacing, perhaps highlighting lack of awareness of permanent nature of procedure.

\section{Attitude}

$70.6 \%$ of females who participated in the study wanted/strongly wanted to practice birth spacing, with only $7.4 \%$ not wanting to practice child spacing. Most of well-educated females (schooling more than $8^{\text {th }}$ standard) wanted to strongly practice child spacing (95\%). Substantial number of females $(70.6 \%)$ considered 2 years as minimum gap for child spacing, with $20 \%$ considering lesser than 2 years also as adequate gap, though education again emerged as an important factor with $85 \%$ of well-educated females (schooling more than 8th standard) wanting atleast 2 years of gap for child spacing. Fewer females with only girl child (s) wanted to practice birth spacing (30\%), even despite being welleducated (schooling more than 8th standard) they were less likely to prefer child spacing $(55 \%)$.

Table 3: Attitude regarding birth spacing.

\begin{tabular}{|c|c|c|}
\hline $\begin{array}{l}\text { Attitude regarding birth } \\
\text { spacing, }(n=500)\end{array}$ & Number & $\%$ \\
\hline \multicolumn{3}{|c|}{ Want to practice birth spacing } \\
\hline Strongly agree & 245 & $49.0 \%$ \\
\hline Agree & 108 & $21.6 \%$ \\
\hline No Idea & 110 & $22.0 \%$ \\
\hline Don't agree & 37 & $7.4 \%$ \\
\hline \multicolumn{3}{|c|}{ Think minimum 2 years of birth spacing is essential } \\
\hline Strongly agree & 328 & $65.6 \%$ \\
\hline Agree & 25 & $5.0 \%$ \\
\hline No idea & 47 & $9.4 \%$ \\
\hline Don't agree & 100 & $20.0 \%$ \\
\hline \multicolumn{3}{|c|}{ Need husband's willingness for spacing } \\
\hline Strongly agree & 320 & $64.0 \%$ \\
\hline Agree & 143 & $28.6 \%$ \\
\hline No idea & 26 & $5.2 \%$ \\
\hline Don't agree & 11 & $2.2 \%$ \\
\hline
\end{tabular}

\section{Practice}

Despite high level of knowledge awareness and inclination for birth spacing, only $40 \%$ of females were practising child spacing. Condom was most widely used birth spacing method, followed by OCP and Copper T. Majority of respondents did not provide reasons for not 
practising birth spacing however it may be linked to husbands and In-law's opposition, which was highest disclosed cause $(14.6 \%)$ of not practising birth spacing. Well-educated females (schooling more than $8^{\text {th }}$ standard) were more likely to be practising child spacing $(65 \%)$ as well as less likely to have husband's or in-law's opposition to child spacing (4\%). Fewer females with only girl child(s) were practicing birth spacing $(25 \%)$.

Table 4: Practice of birth spacing.

\begin{tabular}{|c|c|c|}
\hline $\begin{array}{l}\text { Practice of birth spacing, } \\
(n=500)\end{array}$ & Number & $\%$ \\
\hline \multicolumn{3}{|l|}{ Already practice birth spacing } \\
\hline Yes & 200 & $40.0 \%$ \\
\hline No & 300 & $60.0 \%$ \\
\hline \multicolumn{3}{|l|}{ Birth spacing used } \\
\hline Condom & 81 & $16.2 \%$ \\
\hline Pills & 71 & $14.2 \%$ \\
\hline $\mathrm{CuT}$ & 48 & $9.6 \%$ \\
\hline Not practising birth spacing & 300 & $60.0 \%$ \\
\hline \multicolumn{3}{|l|}{ Why not practising birth spacing } \\
\hline Want a child & 44 & $8.8 \%$ \\
\hline Husband & 55 & $11.0 \%$ \\
\hline In-Laws' pressure & 18 & $3.6 \%$ \\
\hline No Idea of birth spacing means & 68 & $13.6 \%$ \\
\hline No response/don't want to disclose & 314 & $62.8 \%$ \\
\hline
\end{tabular}

\section{DISCUSSION}

Recent study by Nayak et al, reported $100 \%$ awareness of at least one contraceptive method however significant non-usage of contraception (around $11 \%$ of subjects had never used contraception). Partner opposition had been cited as major reason for non-usage of contraception. ${ }^{6}$ Our study also found high awareness, though at $86.4 \%$ a bit lower than urban India, of the means of child spacing. Partner opposition was also the single major factor for not practising birth spacing despite knowledge.

Awareness of birth spacing came from $32.6 \%$ from family/friends and only $23.4 \%$ gained this knowledge from TV/Radio whereas in Srivastava et al's study a much higher percentage $(70 \%)$ had gained knowledge from family/friends and 39\% from TV/radio, highlighting variation in way females gain this knowledge in northern rural India. ${ }^{11}$

Srivastva et al's study reported Copper-T (IUCD) as most commonly known (61\%) temporary means of contraception followed by OCP $(60 \%)$ and condoms $(50 \%)$. This study reported lack of awareness amongst $17 \%$ of respondents, while our study in rural Haryana found lack of awareness of birth spacing means in $13.8 \%$. Our study also found Copper-T as most commonly known means of birth spacing with awareness amongst $55.2 \%$ of respondents, followed by OCP $(49.4 \%)$ and Condoms (21.4\%).
Another consideration in spacing is sex of the prior births, if all of them are females. A study in Nigeria by Fayehun et al, about birth spacing, in a predominantly patrilineal society of Nigeria, reported that the effect of sex of prior births on the birth interval is slightly significant among the patrilineal tribes, who tend to desire to have a male child sooner if preceding births were female. ${ }^{12}$ Our study also found that significantly lesser percentage of similar respondents wanted to practise birth spacing, in rural Haryana a society quite similarly patrilineal.

\section{CONCLUSION}

Present study found that education of females is a major improving factor leading to increased awareness of need as well as benefits of child spacing, with all college studied females being aware of both. Education also leads to improvement in keenness for practising child spacing as well as leading to lesser partner/in-law's opposition to practise of child birthing. Our study also found that females with only girl child(s) were less keen to practise child spacing as compared to those with only boy(s) or those with both girl(s) and boy(s). We also found that in rural geographies health personnel still serve as a significant source imparting awareness of child spacing.

\section{ACKNOWLEDGMENTS}

Authors would like to thank all the specialists, colleagues and staff at the SGT Medical College, especially the interns, students and team who supported us with the data collection despite the busy OPD schedules. Authors would like to thank Dr. Subha Sagar Trivedi, Dr. Banashree Das for her intellectual guidance and support through this study. Author would also record thanks and gratitude to the patients and attendants who interviewed for this study.

\section{Funding: No funding sources}

Conflict of interest: None declared

Ethical approval: The study was approved by the Institutional Ethics Committee

\section{REFERENCES}

1. MacQuarrie K. Marriage and fertility dynamics: the influence of marriage age on the timing of first birth and birth-spacing. Rockville, MD: ICF International. 2016. Report No.: 56

2. Chandna A, Mittal R, Sood A, Sood P. Interpregnancy interval and pregnancy outcome. Int $\mathbf{J}$ Reprod Contracept Obstet Gynecol. 2016;5:415-8.

3. World Health Organization. Report of a WHO Technical Consultation on Birth Spacing. Department of Reproductive Health and Research. Geneva: World Health Organization; 2005. Available at http://apps.who.int/iris/bitstream/10665/69855/1/WH O_RHR_07.1_eng.pdf. Accessed 17 July 2017. 
4. Conde-Agudelo A, Rosas-Bermúdez A, KafuryGoeta AC. Birth spacing and risk of adverse perinatal outcomes, a meta-analysis. JAMA. 2006;295(15):1809-23.

5. Patel A, Pawani C, Patel R. Awareness and acceptance of contraceptive methods among postpartum patients. Int $\mathbf{J}$ Reprod Contracept Obstet Gynecol. 2016 Jan; 5(1):206-9.

6. Nayak AU, Ramakrishnan KG, Venkateswar KN, Vijayshree M. Assessing the knowledge, attitude and practice of contraception in rural India: a necessary step in achieving population control. Int $\mathrm{J}$ Reprod Contracept Obstet Gynecol. 2017 Jul 26;6(8):332831.

7. Kanojia JK, Nirbhavane NC, Toddywala VS, Betrabet SS, Patel SB, Datte S et al. Dynamics of contraceptive practice amongst urban Indian women. Natl Med J India 1996;9:109-12.

8. NHM Health Statistics Information Portal. Data for Maternal Mortality Ratio (MMR), Maternal Mortality Rate and Life Time Risk; [Data file]. National Health Mission: Delhi; 2017. Available at https://nrhmmis.nic.in/Home\%20Page\%20Lib/MMR_Bulletin_2 011-13.xls . Accessed 17 Jul 2017.

9. Government of India. Data for State-wise Per Capita Income and Gross Domestic Product at current prices. [Data file] Press Bureau of India: Delhi; 2014. Available at: http://pib.nic.in/archieve/others/2014/aug/d20140708 01.pdf. Accessed 17 Jul 2017.

10. Matthews Z, Padmadas SS, Hutter I, McEachran J, Brown JJ. Does early childbearing and a sterilization-focused family planning programme in India fuel population growth? Demographic Research. 2009;20:693-720.

11. Srivastava R, Srivastava DK, Jina R, Srivastava K, Sharma N, Sana S. Contraceptive knowledge, attitude and practice (KAP Survey). J Obstet Gynecol India. 2005 Nov;55(6):546-50.

12. Fayehun OA, Omololu OO, Isiugo-Abanihe UC. Sex of preceding child and birth spacing among Nigerian ethnic groups. Afr J Reprod Health. 2011 Jun;15(2):79-89.

Cite this article as: Yadav B, Pandey S. Study of knowledge, attitude, and practice regarding birth spacing and methods available for spacing in rural Haryana, India. Int J Reprod Contracept Obstet Gynecol 2018;7:1389-93. 